Article

\title{
Are We Defending the Indefensible? Reflecting on Policy and Practice Around 'the Border' in Plant Biosecurity for Tree Health
}

\author{
Rehema M. White ${ }^{1, *}$, Mariella Marzano ${ }^{2}$, Sharon Leahy ${ }^{1}$ and Glyn Jones ${ }^{3}$ \\ 1 School of Geography and Sustainable Development, University of St Andrews, St Andrews, \\ Scotland KY16 9AL, UK \\ 2 Forest Research, Northern Research Station, Roslin, Scotland EH25 9SY, UK \\ 3 Fera Science Ltd. National Agri-food Innovation Campus, Sand Hutton, York YO41 1LZ, UK \\ * Correspondence: rehema.white@st-andrews.ac.uk
}

Received: 25 June 2019; Accepted: 15 August 2019; Published: 21 August 2019

\begin{abstract}
The challenges to forest health from climate change, globalization, contemporary trade practices and new recreational patterns require effective biosecurity. We asked: How is the biosecurity border for tree health understood and enacted by state and non-state actors? What are the consequences for tree health? Semi-structured interviews $(N=10)$ were conducted with scientists and other relevant actors $(N=21)$. The border was understood variously as: a biophysical boundary, often the coast; a geopolitical boundary, usually of the European Union; the points of main inspection focus; dispersed nodes of inspection; a 'pre-border' outside of UK; or by the location of detection activities. A wide range of state, non-state and hybrid groups are engaged in border practices. These practices have been altered due to trade and climate changes, are subject to cost and resource priorities and reflect particular knowledge flows and the biological nature of the agents. We suggest that there is an 'everyone' as well as 'everywhere' border that demands clarification of risks, roles and responsibilities, and we offer practical recommendations. We conclude that tree health border challenges are a manifestation of wider sustainability issues that enable us to explore human-nature relationships, democratic engagement and the pursuit of more sustainable futures.
\end{abstract}

Keywords: forest management; tree health; social science; biosecurity; borders; pest; pathogen; governance

\section{Introduction}

Forest health faces significant challenges from climate change, globalization, contemporary trade practices and new recreational patterns [1,2]. Such challenges place pressure on our ability to manage the ecological integrity of forest and woodlands whilst facilitating their capacity to offer economic prosperity and social benefits [3,4]. Increasing threats from invasive plant pests and pathogens require additional biosecurity measures through international agreements, national regulations and inspection systems, as well as sustainable practices within forestry, horticulture, recreation and other relevant areas. Globalization and increased trade create a greater imperative for the monitoring and scrutiny of bio-materials, but also highlight the difficulties of how to do this in practice. The overarching EU approach to plants for planting is general authorization, in contrast to the stricter phytosanitary controls in New Zealand and Australia [5]. There are global measures intended to control pest spread through wood packaging [6]. However, current systems are unable to adequately respond to increasing impacts from old and new pests and pathogens, and the contemporary bio-political context demands novel and urgent action to maintain UK forest health $[7,8]$. It is difficult to estimate the value of the risk from pests and diseases. The UK government's 25 Year Environment Plan Supplementary Evidence 
Report [9] estimates the value that healthy trees and plants contribute to the UK economy, society and environment at $£ 8$ billion per year. However, this is acknowledged to be only a partial estimate, as it does not include, for example, non-woodland trees or benefits to health and well-being. It is suggested that Chalara alone will cost the UK $£ 15$ billion [10]. In the UK, there has been a growing focus on the social and economic dimensions of tree health (see [11]), including recognition of the need to engage with multiple actors in the field [12]. Despite this recent focus, there has so far been no interrogation of how the border is conceived in relation to tree health, how border practices are implemented and how this may influence future tree health. In this paper, we explore linkages across social (state securitization, governance, immigration) and scientific domains of knowledge (pathology, entomology, technology) in order to enhance our ability for biosecurity defense. Discussions around how and where biosecurity threats should be managed have highlighted the importance of understanding the limits of 'the border' and the complexities of its securitization in this arena.

Biosecurity is "a governance approach to a set of concerns that spans the protection of indigenous biological organisms, agricultural systems and human health, from invasive pests and diseases" [13]. It is a collaborative venture across state and non-state actors to identify, plan, implement and regulate management strategies and actions [14]. The shift from government to governance in environmental management, with increasing devolved powers to non-state groups (e.g., [15]) implies that greater non-state control of and responsibility for the border may occur for biosecurity, and the era of austerity can place greater pressures on individual actors [16]. Tree health involves a complex network of actors, including government and government agencies, inspectors, academics, forest practitioners, landscape architects, commercial technology companies, horticultural producers and gardeners and participants in woodland recreation [16-19]. Understanding how these actors interact in order to protect organisms, ecosystems and human health at vulnerable entry points and through control processes is thus essential for biosecurity. In exploring the concept and manifestation of the border in tree health, we first draw on wider understandings of the border.

Much of the academic focus on 'the border' has taken place in relation to human movement rather than plant health. Ramutsindela [20] suggests that although border discourse is now beginning to acknowledge nature, the relationships between nature, non-human materials and the border are under-studied. There is potential for environmental management and biosecurity practice to benefit from the ways in which the border has been theorized. The border is no longer only situated at what was traditionally seen as the physical territorial boundary of the nation state.

Although states attempt to choregraph national borders, often in response to global pressures, these state policies have little meaning until they are "performed" by state agents or by border crossers ... Border agents and state bureaucrats play a critical role in determining where, how and on whose body a border will be performed. [21] (p. 66)

Borders are thus now seen as much more than distinct, fixed lines on a map; they are presently at the heart of many social, political, cultural and environmental processes [22]. The traditional view of 'bounded national geography' or the 'container view of the nation state' have been unsettled by greater human mobility, whilst global environmental concerns such as climate change have eroded the connection between territory and sovereignty [23]. Borders are not only technical spaces to exert control over what passes through, but simultaneously they are discursive landscapes of social control [24]. Indeed, borders are "processes, practices, discourses, symbols, institutions, or networks through which power works" [25] (p. 62). These discursive and technical spaces are influenced by scale, location and temporal factors. Recent studies have highlighted the ubiquitous nature of an "everywhere border" that is "everywhere apparent" [26] and has the potential to be actualized at any time [27,28]. The border and its various enactments are now more commonplace; borders are to be found in multiple venues and are evident at a multitude of scales. They are "things within the space of the political itself" [26] (p. 92). Border studies have been reinvigorated over the past decade, with a special focus on the securitization and militarization of the border in the face of human migration (e.g., [29,30]). These studies tend 
to focus less on infrastructure and formal practice at the border and more on border processes that are being normalized within social relations away from the physical limits of the State. Increased globalized trade has also led to a transformation in the way in which borders work, with Balibar noting how social and economic forms of globalization have "relativized the functions of the port of entry and, by contrast, revalorized internal controls, creating within each territory zones of transit and transition" [26] (p. 90).

Borders are thus now both moving into the day-to-day actions of the state itself and are being transferred to many sites beyond the sovereignty of the state. Mountz [30] argues that ports of entry are increasingly mobile, both moving into and out of the sovereign state territory. Movement, circulation and transport are intrinsic to any study of the border, and the flow of goods and people is fundamental in this global era. However, such movement creates complex issues in relation to sovereignty, jurisdiction, policy and accountability, which need to balance control with movement and commerce, and raise questions of power, responsibility and knowledge.

The transit and transition zones identified by Balibar [26] are especially important when considering how borders work for the mobility and control of non-human materials, such as plant materials and wood products. Balibar speaks directly to this shift and potential decline in control, utilizing examples from the Chernobyl disaster and the spread of the AIDS virus, arguing that borders work differently for material things than for people, "not to mention what is neither thing nor person: viruses, information, ideas" [26] (p. 91). With this in mind, he goes so far as to question "whether things transport, send and receive people" [26] (p. 91), rather than vice versa. Whilst some pests and pathogens are airborne, others enter a territorial region on plants or other products (biomaterials), usually through ports. Control and appraisal take place at various points from the area of departure to its arrival in the UK, in line with the new UK Biological Security Strategy [31]. However, these controls are dependent on each inspector's relative effectiveness (based upon level of knowledge of potential hazards, access to technology to ascertain these risks and the methodical nature of their scrutiny), and their power and authority to make these judgments [17]. For biomaterials, hazards can also be picked up and amassed along this route, thus making the risks more difficult to ascertain. Determinations of what to inspect and when to do it are made on assessments of this potential risk using experience, protocols and regulations such as the UK Risk Register [32]. Amoore [33] discusses how a virtual border of risk determination is created, with responsibilities emerging for state and non-state operators. Border security can be seen as a transformation of sovereignty that takes place across different jurisdictions; for example, in the oceans around an island state [29]. This notion of a virtual border in terms of human movement is interesting to explore further in terms of biosecurity. Human passengers are subject to risk profiling and biometric security measures within a virtual border, and this decision- making process and the responsibilities of control raise issues around obligation in relation to biosecurity [33]. For example, if biomaterials are bound for the UK, should non-UK port operatives and inspectors share the obligation to inspect all materials passing through their ports, or should the obligation, responsibility and commitment be left to UK port inspectors? The balance between detection and efficiency is crucial, because UK ports are privately owned and run as competitive businesses under pressure to process imports as rapidly and effectively as possible. Border discourse discusses this in relation to 'border performance'. Salter outlined a tripartite system of border performances (see [25]) including: (1) a formal border performance associated with the prescribed territorial assertions of power through border points, regulations and expectations; (2) the practical everyday performance of the border, which recognizes that the day-to-day implementation of regulations can, through activities of inspectors, manifest in different behaviors; and (3) the popular nature of border performance, which acknowledges how borders entrap our thinking, and whereby different actors will interpret and understand borders in diverse ways. Borders consequently are seen as working functionally, figuratively and imaginatively. For tree health, it will thus be useful to understand the operation of the contemporary border using these three lenses to develop insights on regulation, border practices and the ways in which we communicate and consider biosecurity requirements. Given the new multiple 
risks from pests and pathogens and the diverse group of actors involved at and beyond the border, can we defend our tree health, or is it in fact indefensible?

We address four research questions: (1) How is the biosecurity border for tree health understood and performed? (2) How do various non-state and state actors collaborate to secure the border? (3) Is the 'everywhere border' a useful concept for biosecurity? (4) What are the consequences of border concepts and practices for tree health and biosecurity? We thus offer new conceptual insights into 'the border' in relation to tree health, and we provide practical recommendations for the regulation and management of forest biosecurity.

We begin by detailing our methods, using interviews and focus groups with state and non-state actors across the tree health sector. We offer coded results from our data, exploring the manifestation of the border, border performance, management of the detection of tree pests and the properties displayed by biomaterials. We finish with a discussion of conceptual insights and practical recommendations for tree health.

\section{Materials and Methods}

This study emerged out of an association with a large, interdisciplinary research project focused on the development of new technologies for the early detection of pests and pathogens within the UK, along with an exploration of how technologies can best be deployed and knowledge exchanged [16,17]. The five technologies explored were (1) volatile organic compounds, to identify chemical changes in the air triggered by disease; (2) spectral imaging techniques, to detect visual changes in plants caused by disease and stress that are beyond the range of human vision; (3) new pheromone traps to capture insects; and molecular genetics approaches using novel techniques such as (4) water borne disease transfer and (5) fungal spore analysis. The project also explored which stakeholders are involved in early detection and how they could best work together. The term 'stakeholder' has several connotations; it emerged from business management and generally denotes an individual or organization with an interest in an issue that is often affecting or being affected by the issue [18,34,35]. However, this definition belies an emotional or moral choice in perspective or practice (e.g., [36]) and emphasizes the 'stake' or interest of the individual. It has been suggested that the use of the term 'actor' better acknowledges these aspects, and permits us to see research participants more widely as people [37]. Whilst in our initial study we felt it appropriate to consider the interests of 'stakeholders', in this paper we recognize that, for some individuals, interest is not dictated only by role, and we thus term those working in the field of tree health as 'actors'.

We developed a database of relevant actors, held annual interactive one day workshops with all of these actors, invited the use of novel communication techniques to engage different groups and developed socio-technological learning labs (SLLs) to encourage engagement within particular contexts (e.g., with inspectors at an airport and a port inspection facility) as well as a learning platform [16,17]. Project meetings included focus group discussions within the wider project team. We undertook one or two semi-structured interviews with the project technology scientists $(N=10$ in total) and with a broad range of actors, including individuals from public and private sector forestry, conservation, industry (specifically nurseries), policy and community woodlands $(N=21)$. Questions tackled project engagement, use and opportunities for technologies and how participants perceived and understood 'the border' in relation to plant health and wider plant biosecurity. Interviews (30-90 min) were professionally transcribed and coded using both inductive and deductive coding [38] against themes and actor roles. We also discussed 'the border' in team focus groups and with participants in SLLs. Finally, we held a session in our second learning platform workshop in which we asked participants to create a vision for biosecurity with relation to tree health in small groups, then to discuss what steps we might take to get there and share small group outcomes in a plenary discussion. Notes from these sessions were coded primarily against interview themes, with some additional themes emerging. All interviewees gave their informed consent for inclusion before they participated in the 
study. The study was conducted in accordance with the Declaration of Helsinki, and the protocol was approved by the University of St Andrews Ethics Committee.

\section{Results}

\subsection{Understandings of 'the Border' in Tree Health Biosecurity}

When exploring how the biosecurity border for tree health is understood and manifested by different participants, we received varied responses (see Figure 1). At a focus group with scientists at the beginning of the project, we used maps of the UK to explore the areas on which we should focus efforts on early detection of tree diseases. Opinions differed depending on the role of the participant, and on which pests or pathogens they most worked with. Scientists working closely with plant inspection agencies or with larger pests (such as beetles rather than fungal spores) saw the sea and air ports as being critical border points, rather than there being a homogeneous coastal border. Discussion revealed that this view might be simplistic as some plant material was shipped on containers that were not opened until the end destination such as at a plant nursery. In this scenario, there was potential to infect other plants at scattered nursery entry 'points' across the country. Other scientists shaded the North Sea because they worked on spores that could come across the ocean-they perceived a diffuse area of potential 'border' to patrol. Others saw a line of defense, which differed again depending on the species and type of technology of interest to them. For example, some species are constrained by habitat conditions and might enter the country, but their spread can be limited by altitudinal or latitudinal gradients, or increased as a result of climate change. These patterns of movement illustrated the potential entry of alien pests or pathogens and an attempt to identify and eliminate them once they were inside the UK border. It was agreed that whilst our island's coast creates the illusion of an encircling, well-defined border, the border for the early detection of tree pests and pathogens in fact manifests in diverse ways (point, linear, diffuse). It can manifest in different places depending on the regulatory and inspection regime, biophysical characteristics and perceived pest threat, as well as the form of detection technology (Figure 1).

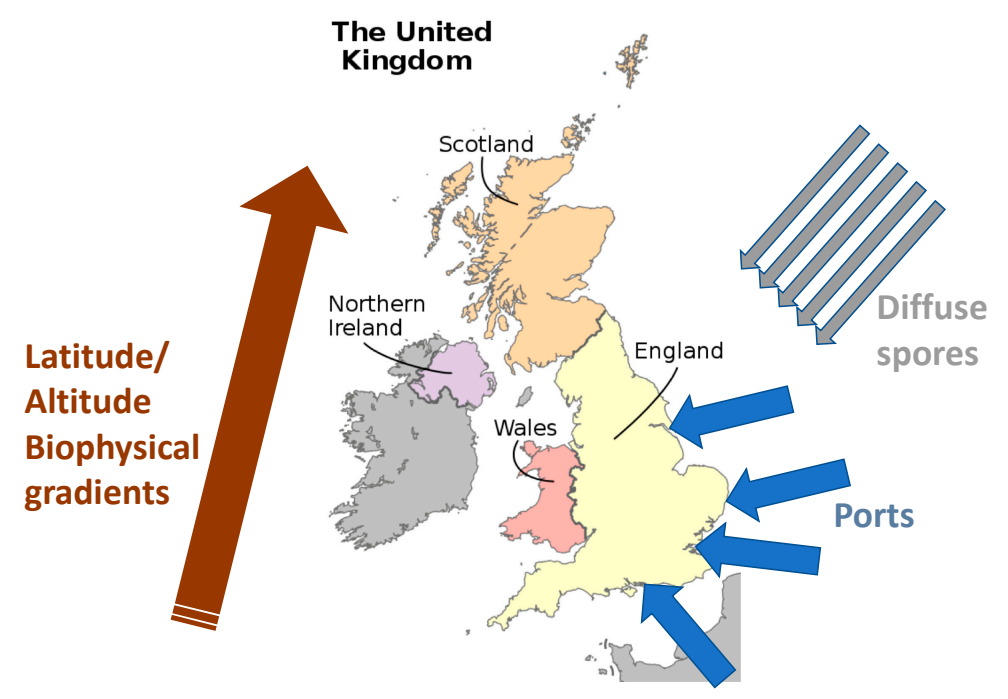

Figure 1. Perspectives on 'the border' for early detection of tree pests and pathogens as provided by scientists early within the study.

These perspectives were elaborated on in terms of biophysical definitions and human practices from interviews with a wider range of actors. It became clear that many respondents struggled to clearly define what and where 'the border' was in relation to tree health: "the border between what and of what?" (scientist); "I see it as open, it's a difficult thing" (conservation volunteer). Clarifying the 
term 'border' led to different ideas of what, as well as where, the border was. There was an awareness of multiple locations and forms of borders, but the specifics differed among actors.

Firstly, some respondents raised debate about the effective nature of a border as barrier for pathogens:

Obviously we've got the political borders being Europe and the UK as an island, but again when it's diseases affecting our native plants there's not really any borders. The borders are so porous that we can get spores of Chalara being blown over the channel in the wind and there aren't really borders at all, are there? (government agency staff)

The border as an idea may not be suitable either: "You wonder whether the concept of a border is useful at all, in, in, you know in the way we thought of things traditionally" (NGO member).

Secondly, the border could be defined in terms of biophysical characteristics and habitat requirements for the spread or survival of particular pests or pathogens:

The border is the geographic line for where that disease can be or not ... like you wouldn't go looking for certain plant pests and diseases up in the North Pole or something, would you, because you know they can't survive there .... so country borders are a total irrelevance. (tree nursery owner)

This perspective related to definitions of borders as current pest or pathogen distribution areas: "The border to me is the Phytophthora part of Europe, then anywhere outside it ... the border is between where it [Phytophthora] is, and it isn't" (tree nursery owner).

As respondents were considering the border from their own geographic location in the UK, several noted the importance of physically being an island: "well, an island's a border" (tree nursery owner). The island edge was seen to be like a moat or fortress defense: "Like most of us kind of island dwellers, I regard the North Sea and the Channel as something of a potential hindrance to some types of diseases, and once it has made that jump across into the UK, usually it's game up" (forester). Another respondent supported the view above that political borders were ineffective and "it [the coast] is a natural barrier, where you would have the potential to stop [disease]" (tree nursery owner).

Despite reservations about the efficacy of a border, or dependence on biophysical characteristics, many respondents did suggest that borders could also be defined, thirdly, by geo-political parameters. Some saw the border as being politically demarcated, such as a boundary around a devolved area within the UK- "in Scotland we've got an obvious political border" (conservation NGO representative)-although there was concern about the rationality of this boundary for tree health: "a border between Scotland and England can still be irrelevant" (tree nursery owner). The political demarcation of the UK itself was also important, but many understood that once biomaterials were in Europe, they were subject to free movement and so 'the border' may span this wider geo-political region: "... . it's a geographical border as in the UK. Although it's not even that, obviously Europe" (government agency staff). "There's a single market, there is no border between member states. The border is first point of landing into an EU member state from a Third Country, that's the border" (inspector). There was some concern about this manifestation of borders being the edge of the European Union: "if there is a constant stream of stuff coming across from mainland Europe, then it's a bit of a problem" (NGO staff member).

Another respondent expanded on an example in relation to this:

In some respects, I think my border is the EU, because obviously once things get inside the EU, there's often not much monitoring or concern, and clearly that's what happened with Chalara [ash dieback (Hymenoscyphus fraxineus (T. Kowalski) Baral)], that it sort of swept through Europe pretty much unchecked. (NGO staff member)

There was a perceived lack of control regarding the EU border; an inspector suggested that some Third Countries might select less well controlled entry points ("weaker links") to the EU for import and 
there was concern over particular border stretches "apparently it's a very leaky border" (government agency staff).

Fourthly, 'the border' was seen by many to not be a line or boundary but rather a collection of points of entry: "our border starts, it's a point of entry with imports" (government agency staff); "at the point of import" (scientist); "initially you think the borders are ... points of entry and things like that" (scientist).

Whilst several respondents mentioned sea ports or airports, one scientist commented that the biomaterial in which he was interested mostly arrives in trucks across the Channel. However, several respondents spoke beyond point of entry and included points of arrival, unpacking of containers or other transport and possible inspection, creating a fifth and more dispersed vision of 'the border': "But I think probably it's a bit more diffuse than that [points of entry] and it moves into ... the stone-yards, nurseries ... or the garden centers" (scientist).

Indeed, one scientist described his efforts to understand how border control was implemented within the country:

Those shipments [imports] are tracked, it's known where they go to, so then it becomes other than a pre-border or border inspection, it becomes a post border inspection. It becomes a trying to check them while they're in quarantine or a holding position in the nurseries.

For some respondents with personal and particular interests in tree health, especially two nursery owners, the boundary of their property or business formed the initial border; rather than seeing their business as a point for pests coming into the country, they viewed their property as a location to keep pests out of the country. Another respondent reinforced this dispersed model of the border occurring around places of unpacking and inspection, and suggested a temporal dimension to the border because larvae or caterpillars might hatch or fly later: "the border of where you would put your detection activities is definitely much more within the country than just the port" (scientist).

Sixthly, it was recognized that the border could be in another country planning to import to UK, not necessarily in the EU, because pre-border checks could take place, for example, in Third Countries. The need for inspections in country of origin was discussed by several respondents: "Clearly, it's done prior to that [importation] ... which is why inspectors quite often go out to various countries to help improve their detection and their methods and approaches" (government agency staff). Alternatively, inspection can occur on transport or in transfer locations before reaching the UK: "the inspectors do sometimes go onto ships and inspect before they are unloaded" (scientist), and "there's an inspection point apparently, at the port at the other end of the tunnel, on the French side" (scientist).

It was suggested that some technologies might be applied before importation to gain pre-border certification:

We should continue to develop the technology and perhaps build it in to a pre-border check, so that the producers who want to sell plants to us could use the technology to say 'yeah these have been tested by this method and have shown be free of disease'. (scientist)

In a final manifestation, the border was also recognized in terms of the performance of the border (e.g., inspection practices), for example, as "where you put your detection activities" (scientist), or "the definition of border is that it's somewhere where you can stop and hold something, and I presume do your inspection" (tree nursery owner).

Hence, whilst the concept of border was new to some respondents, on reflection the border was understood variously as: (1) a virtual concept of dubious utility; (2) a biophysical boundary, often but not always identified as the coast of mainland Great Britain; (3) a geopolitical boundary usually recognized to extend to the boundary of the European Union; (4) the points of main inspection focus; (5) dispersed nodes of inspection by different actors; (6) a 'pre-border' outside of the UK before importation of plants; or, finally, (7) by the location of various detection activities-in other words, the performance of the border. 


\subsection{Border Performances: Actors, Roles and Risks}

Border performance can be perceived as formal regulations enacted by and conferring authority [29], or as the day-to-day activities of those involved (Salter in [25]), and this performance can occur in relation to different concepts of the border (as discussed above). A variety of state and non-state actors are involved in tree health [16-19] and many of these actors were identified as being involved in border performance.

Some respondents suggested that border regulation in principle (formal border performance) does not always align with border performance in practice. In fact, border was seen by one government official to be the location of detection efforts, or the arena of border performance. Personal agency and institutional power also influenced perspectives on border performance. For example, one government agency staff member declared that: "Scotland is the border, you know, and my powers don't exceed over the border."

One commercial agent suggested that not only did performance define where the border was, but also the efficacy of the border: "It's more of an impassible place - or it should be an impassible place." However, this respondent also commented that, in practice, "arguably for pest and disease, the borders are too porous at the moment". This view revealed that whilst formal regulations of the border existed, they were not able to completely repel pest or pathogen invasion. Some respondents recognized diversity in the potential invasion of pests and pathogens as well as in actors. Whilst some pests and pathogens should be tackled, some diseases were likely to cross borders and naturalize eventually, and we could be "learning to live with some of the others" (forester). However, this forester also suggested that "we've got a very clear opportunity I think, to limit the ingress of insect pests into this country, if we control our physical geographic borders."

Respondents noted the devolution of border control from state to non-state actors in some cases. It was recognized that there are many actors potentially involved, but that it is challenging to coordinate and galvanize them.

It's not just forestry or arboriculture, is it? Because there are so many other relevant and related industries and sectors, which can impact on the health and vitality of our trees and forests, so it's how do they interrelate and how do we get some understanding around about sustainable procurement... ? (forester)

Whilst certain private sector actors were keen to be involved in the early detection of plant pests and pathogens, several respondents indicated concern about particular business types or sectors. Although these allegations are unproven, they indicate a lack of trust and a need for more transparent collaboration among businesses and across public and private sectors.

Some sections of government are considering "exploring surveillance possibilities using citizen science", especially "very well trained volunteers" (government agency staff), and there was enthusiastic comment about this potential:

Early detection is not just about the statutory authorities, it's about involving other stakeholders and the nursery owners and their landowners or whether it's through projects such as [a particular] citizen science project. You know there is a whole range of volunteers and people out there that can be helping protect our borders and involved in early detection. (government agency staff)

Other non-state contributions to surveillance were discussed. One forester noted the value of the embodied experience and "eyes on the ground" of experienced foresters who regularly work in forests as a potential support to early detection if harnessed appropriately:

We're kind of sharp eyed and if tree diseases get more on the radar of tree professionals in the field, you know, obviously we are a potential source of knowledge if that can be harnessed, simply because we are out there, whereas you guys in universities or research stations aren't out there so much. (forester) 
It was accepted that whilst imports pose a threat, significant reduction in imports would probably not be accepted by suppliers or consumers: "if there's no imports, then that takes away the route [for disease transmission]. But everybody seems to be hellbent on keeping imports" (tree nursery owner).

There was more discussion of how 'the public' might enact sustainable choices and behaviors with regards to tree disease, and it was suggested that in many cases people were just not aware of the origins and threats posed by biomaterials: "when they're buying firewood for their afternoon barbecue, if it happens to be a nice Saturday, they're not thinking about the provenance of that wood at all" (government agency staff).

It was observed that plants can be purchased on the internet and imported and there was some discussion of how other states perform border inspections and controls in relation to tree health. There were statements suggesting deeper reconfiguration of supply chains, for example, in the nursery sector:

We need to start by setting an example and making sure that we procure our material from homegrown, British grown nurseries, because there's really no excuse for not doing so, and equally for making sure that now our procurement and plant material is fit for purpose, so not always demanding that we have extra heavy sand that is coming over for particularly ornate species that can't be got here. You know we should just be realistic about what we can get. (forester)

Whilst there was some debate over roles in border control, there was also discussion regarding risks, responsibilities and consequences. Certainly, all respondents noted in some way an imperative to consider and manage tree health as well as possible. One forest manager noted that "there's a real obligation there, not only in terms of procurement of timber goods but anything else, plant material, horticultural material, that comes in from elsewhere".

Border performance is also affected by wider trade and policy contexts that cause certain practices to occur; for example, there is a commercial business risk that is linked to tree planting policy. Large numbers of young trees are purchased each year, for example, to fulfil the tree planting aims derived from the EU-funded Rural Development Programmes. The planting prescriptions within grants often change. Nurseries need to make decisions regarding stock availability and planting up to three years ahead of the expected demand from grant schemes. However, any changes to the prescription would make any tree stock held prior to the change much less valuable or even worthless. In order to prevent such a situation, or at least to reduce the risk, the nurseries will not grow $100 \%$ of their expected demand. Rather, many nurseries will import more stock, despite an associated pest and disease risk. A commercial agent expressed concern about these risks and uncertainties facing domestic tree nurseries. He said: "It's shared risk. You can't have one person in the chain taking all the risk." This individual explained some of the current practices that he felt nurseries were forced to take to reduce commercial risk exposure:

So prior to growing contracts, if you like, and I think some of the nurseries at the moment are going through the pain, is that they grow speculatively, if it goes wrong, and growers cancel or the order changes, then it's the nursery that suffers and they end up burning trees. So they're not going to do that, what they then do is hedge their supply amongst a number of different nurseries who probably hedge their supply against another number of other nurseries, so this is where it starts to get more and more complicated and at some stage or other, it goes over the channel and that's when the risk comes in. (tree nursery operator)

One nursery owner commented that they could be affected by risks elsewhere with serious consequences for them, and that identification of a reportable disease in a nearby garden center could negatively influence them: "You know it's stuff that is totally out with my control, it would mean that it would put me out of business" (tree nursery owner).

There was thus perceived risk to an individual, a business and a sector, as well as an ecosystem risk of invasive tree pests and pathogens. Risks were identified in relation to economic viability, and also 
to the possibility of pest or pathogen invasion. Current practices had been driven by commercial pressures and policy, and by the globalized nature of trade, and only when there was a 'fright' (due to detected tree disease and loss of stock) would this risky practice cease.

The tools and methods used in border performance also varied, depending on the actor, pest and context. Early detection of tree pests and pathogens requires skills, such as the "eyes on the ground" (noted by a forester) of practitioners and the visual examination by inspectors. Although technology can enhance detection of pests and pathogens, the application of technologies is not the only answer. One scientist reported that:

We can't really practically apply the technology at a border. There are not [enough] inspectors, inspectors don't actually inspect plants to the level of detail in transit, the same way we imagined when the project started.

This section has revealed that not only is the notion of the border complex and varied, but also that the actors and actor roles involved in border performance are multiple and diverse. Because the differentiation of state and non-state actors is important in border literature (e.g., [26]), we began to organize our tree health actors in this way, but the recent shift to more hybrid forms of organizations involved in tree health (see [16]) led to a further categorization. A summary of the state and non-state actors, and those now belonging to hybrid organizations along with their main roles in early detection of tree pests and pathogens, is shown in Table 1.

Table 1. Summary of the roles of state and non-state actors in tree health early detection identified throughout the project (from this study and informed by $[14,15]$ ).

\begin{tabular}{|c|c|c|}
\hline Actor & $\begin{array}{l}\text { State (S); Non-State } \\
\text { (NS); Hybrid (H) }\end{array}$ & Roles in Early Detection of Tree Health \\
\hline Policy makers & S & $\begin{array}{l}\text { Develop strategy and regulation regarding pre-border testing and } \\
\text { phytosanitary certificates for plants; post-border statutory reporting of } \\
\text { selected organisms; border inspections }\end{array}$ \\
\hline Inspectors & S & $\begin{array}{l}\text { Responsible for undertaking inspections at points of entry, other } \\
\text { checkpoints and reported incidents, and recently some in-field diagnostics }\end{array}$ \\
\hline $\begin{array}{l}\text { Government } \\
\text { agencies }\end{array}$ & $\mathrm{S}, \mathrm{H}$ & $\begin{array}{l}\text { Contribute to policy development and regulation, research, public } \\
\text { engagement }\end{array}$ \\
\hline $\begin{array}{l}\text { Diagnostic } \\
\text { laboratories }\end{array}$ & S, NS, H & Conduct diagnostic testing \\
\hline $\begin{array}{l}\text { Commercial } \\
\text { laboratories }\end{array}$ & S, NS, H & Develop technologies, develop commercial products from concepts \\
\hline $\begin{array}{c}\text { Forest } \\
\text { practitioners }\end{array}$ & S, NS, H & $\begin{array}{l}\text { In-field observation for pests, sustainable forest management, commercial } \\
\text { planting decisions regarding species and origin, reporting pests }\end{array}$ \\
\hline Academics & S, NS, H & Pest ecology, develop technologies, social science of tree health \\
\hline Tree nurseries & NS & $\begin{array}{l}\text { Grow and sell trees, import, quarantine, self-report for the 'good of the } \\
\text { industry' }\end{array}$ \\
\hline $\begin{array}{l}\text { Landscape } \\
\text { architects }\end{array}$ & NS & $\begin{array}{l}\text { Buy and plant trees in large quantities, especially along new roads; need to } \\
\text { check provenance of plants }\end{array}$ \\
\hline $\begin{array}{l}\text { Horticultural } \\
\text { businesses }\end{array}$ & NS & $\begin{array}{l}\text { Import and sell wholesale and retail plants; can be involved in garden } \\
\text { design, planting and trends; need to model and provide good practice and } \\
\text { inform the gardening public }\end{array}$ \\
\hline Communities & NS & $\begin{array}{l}\text { Manage decisions from tiny community woodlands to large forests } \\
\text { regarding species, planting, management, observation, reporting }\end{array}$ \\
\hline Citizen science & NS & $\begin{array}{l}\text { Projects harness raised awareness and amateur expertise, and may offer } \\
\text { surveillance potential }\end{array}$ \\
\hline 'The public' & NS & $\begin{array}{l}\text { Need to be engaged in phytosanitary behaviors to assert vigilance and } \\
\text { report statutory pests }\end{array}$ \\
\hline NGOs & NS & $\begin{array}{l}\text { Support community woodlands, activities in woods, awareness, } \\
\text { engagement (e.g., outdoor learning, citizen science, environmental } \\
\text { education) }\end{array}$ \\
\hline
\end{tabular}




\subsection{Border Performance: Resource and Knowledge Requirements}

It was noted that the nature of borders had changed over time, becoming harder to define and control: "the border is somewhat notional, and becomes more and more notional, as we have more and more international trade in plants" (forester).

There has been a perceived shift towards 'porous borders' because of this increased trade: "one of the things now though, is how porous borders have become generally, so any border is not that significant when you've got trade moving things around so much" (NGO member).

It was recognized that inspection of borders has costs and that the degree of border control is influenced by "the quantities of staff" (inspector). Also, existence of a regulation may not mean that it can be fully implemented, due to staffing, resources and multiple points of entry: "They need enough resources to make sure they can police everything coming in" (tree nursery owner). The role of citizen science may be "cost effective" (government agency staff) but still requires financial support. This individual said "it comes down to being paid, in terms of resource and money to deploy those technologies [in citizen science]".

Budget allocation could contribute to the definition of the border and border control practices:

It is one single pot of money for instance, for Scotland, England and Wales, even financially and operationally it's delivered on the England and Wales basis, so there aren't any borders [between devolved areas] in that respect. (government official)

The importance of knowledge and communication not only across actors within the UK but also with other countries was raised: "we need advanced warning of things arriving, and we also need advance warning of things in other countries that pose a threat" (forester). Border control needs to be more predictive and able to draw on international knowledge flows:

That was potentially one of the flaws of Chalara that we had 20 years of people kind of at some level knowing that this thing was present in Russia and Eastern Europe and making its way towards us. And yet it's only when it started jumping over the North Sea and the Channel to get here that we started to get interested. Which is obviously a problem, and so whilst it's important that we have early detection of things arriving here, it's probably equally important that we are talking to colleagues abroad about the things they've got that may pose a threat to other countries. (forester)

\subsection{Properties of Biomaterials}

Certain particularities of biomaterials and the biological natures of the objects against which the border was being secured were raised in relation to border performance. Two scientists pointed out that imported products might contain a caterpillar or larva, which then morphs into a beetle or other form of the species over the time of transport. The biological nature of concerns was also reflected in the emphasis of the island coastal 'border' as proposed above, creating a biophysical boundary as well as a geopolitical one: "the most significant border is probably the one around the island, because it's the most natural break to the spread of things" (NGO member).

Perhaps we need to distinguish between naturalized and anthropocentric biological threats in relation to the border, and a forest manager suggested that

It's trying to recognise about what sort of naturalisation in terms of spread of pests and diseases that we will just have to cope with, and what is physically dealing with things which, shouldn't be here, like Asian Longhorn Beetle, for example, ... here because of human intervention.

A forestry consultant and a forest manager commented that border control and consequences might differ across biological groups; it may be possible to detect and control an insect after it arrives in the UK, but it would be more difficult to contain a fungal pathogen once in the country. It was 
also indicated that pre-border control may be more desirable than for human movement, given the nature of biological spread of disease: "there are very few examples where we've managed to get on top of a tree disease that has arrived, so it seems to me the border is at its closest, in a sense, over the channel" (forester).

It was noted that the impacts of tree pests and pathogens might vary across bio-regions: "I don't think the Ash population was that massive [on mainland Europe] but then it [Chalara] reaches the UK and it's a massive problem" (NGO member). Depending on origin and type of pest or pathogen, "it seems to me that when you get things that haven't co-evolved in any way at all that you get that catastrophe" (forester). Several respondents mentioned climate change as influencing spread and survival of incoming pests and pathogens, making the importance of borders to disease spread less significant. For example, one forester commented: "it [Dochistoma] is a native disease but it's becoming a problem now, possibly due to climate change where it wasn't previously so, so borders are irrelevant in that sense."

Hence, we see that 'border' is understood and manifested in different ways. It is performed by a complex suite of actors performing different roles. The intentions for management of tree health have changed over time. They are subject to cost and resource priorities and reflect particular forms of knowledge flow. Finally, the biological nature of the agents against which we need to secure the border influences how we need to respond.

\section{Discussion}

In this paper, we aimed to explore how the biosecurity border for tree health is understood and manifested, which actors defend the border and how, the possibility of the 'everywhere border' for biosecurity and the consequences of border concepts and practices for tree health and biosecurity. We now discuss the results to address these questions.

These results demonstrate that there is a wide range of state and non-state actors and some hybrid actors across state and non-state domains (such as government agencies that have been privatized; see also [16-19] for more complete actor analysis) with a vested interest in border surveillance and protection against outside disease. These actors collaborate and/or compete within a complex network of relationships and activities to detect pests and pathogens against a border that is perceived and interacted with in multiple ways. Whilst a few actors questioned the efficacy of the border as a concept at all, others suggested it can be biophysical or geo-political, centralized or diffuse, defined by activity or regulation and species-specific or malleable. The results illustrate the complicated nature of the border and the complexities inherent in policing the various entry routes into the UK. Many of the issues outlined in the data are compounded by the UK's island location. The responses showcased different perspectives on what and where the border is, providing diverse meanings of the border (Salter in [25]), and underscored the real difficulties inherent in preventing pest and disease progression to the UK. Whilst this study is novel in applying the concept and performance of the border to tree health, we can draw on wider thinking in relation to the border for human movement to identify contemporary issues and develop potential biosecurity recommendations.

\subsection{The 'Everywhere Border'}

Our research revealed that notions of what and where the border is varies across actors and perspectives. These subjectivities around border operation reinforce the view of the potential discursive impact of the border [27]. The different perspectives of those involved in border security can lead to "entrapped border thinking" [22] and prevent actors from understanding each other's roles and views and collaborating for an effective and fair "performance" of border (Salter in [25]). In our study, many individuals agreed that 'the border' in tree health is dispersed across key entry or import points, places of inspection and locations in which imported plants and other materials are unloaded or unpacked. This issue of dispersal means that the border occurs in intermediate and end locations, and consequently that the border can be in a commercial forest, a community woodland, 
a commercial nursery or a private garden. This becomes a further manifestation of the 'everywhere border' [26]. In line with Balibar's proposals, we see that biomaterials pose particular complications for border control because of their mobility and biological attributes. We elaborate here on how biological properties of potential pests and pathogens create a multiplicity of border spaces. These are dependent on, firstly, biological categorization (e.g., fungal spores drifting across the wind; insects crawling out of packing material). Secondly, there are temporal effects (such as caterpillars hatching or larvae morphing, with a more mature threat flying off into the trees). Finally, border spaces can be influenced by environmental interaction (such as responses to climate change). The biodiversity of pests and pathogens creates additional challenges; vigilant and informed "eyes on the ground" (forester) are required to spot these camouflaged threats, but the diversity may need to be detected through 'technology' that may only be accessed by particular actors with authority.

Our respondents indicated how borders can be defined by the processes and practices of detection activity, in line with previous research $[24,25]$. Borders are not only technical spaces of social power, and the differences in perception demonstrate that the border in biosecurity is not fixed and immutable, but is characterized as a discursive space of social control (see [24]). For example, our results show that the border can be at fixed points of arrival if subject to inspection when imports are unpacked. As Agnew and others [22] have argued, borders are dynamic, not inactive; as shown above, they are characterized by their multiplicity. The work of Burridge [39] on the 'polymorphic' nature of borders underlines how borders can take a variety of forms. To secure these multiple sites, 'borderwork' is required, stressing the processual nature of borders and how they appear, a phenomenon on which Sohn [40] calls for further study. This notion is in line with the variations in 'border performance' in practice demonstrated in this study.

Not only are there spatial and discursive differences in the way the border is perceived for tree health, as noted above, there are also temporal variations. In some cases, these relate to naturalized 'pests' or those considered to be beyond control; in other cases, 'new' threats are identified and sought. New potential threats can change the nature of the border (e.g., point or diffusion) and the technical facilities required to detect and control it (such as new genetic coding). Understanding this can assist us in making strategic decisions about where to invest inspection effort, training or regulation to support border control against plant pests and pathogens. For example, targeting key points of supply chains would be a useful strategy for border performance in formal and practice terms.

\subsection{Roles, Risks, Responsibilities and Resources}

A collaborative and integrated process of borderwork, and effective practice of 'border performance', is required across state and non-state actors to limit pest import/spread, but this inherently raises questions regarding roles, risks, responsibilities and resources. Different roles are held by different actors (Table 1), but whilst in some cases these are active roles, in other cases the roles are not even known. Not all of 'the public' are aware of or capable of an active frontline defense against tree pest and pathogens. Hence, whilst passive surveillance by 'the public' is imperati e, a strategy integrating this with active surveillance by inspectors is required [41].

Some aspects of a virtual border of risk [33] have been observed, with talk of potential threat and where this might manifest and how it might be borne. Risk (economic and ecological) was present at different scales. Risk was dependent partly on the type and extent of invasion of a new pest to an area, how severe the pest effect might be and on perceptions of the value of maintaining healthy ecosystems. Concerns regarding risk were held across different domains: private businesses (such as individual nurseries) and wider industries (such as the nursery sector, commercial forestry), state (national environmental integrity for the public good) and cultural and emotional discourses. Risk was understood in different ways specifically across economic and biological spheres. It has been seen that in order to minimize financial risk, nursery owners have to accommodate genetic risk, but by purchasing plants from across Europe (albeit with trusted suppliers), they expose themselves and the country to potential biosecurity risks, because they may unintentionally import a pest or 
pathogen. At the same time, individual businesses bare the risk of certain pests being identified on their property. As well as issues around sourcing, there was a suggestion that some businesses sell and release plants without quarantine due to constraints in space and immediate consumer demand. This reduces individual business risk but exacerbates national risk by dispersing plants potentially carrying pests. An important characteristic of biosecurity is that it is described as a weakest link public good (others benefit from its application and you cannot prevent them benefitting) and thus will be underprovided by the market place.

Responsibility is shifting from state to non-state actors, in line with a general shift from government to governance in environmental management (e.g., [15]). As the border becomes more malleable and dispersed across multiple locations, the need for a variety of actors to become involved in performing borderwork becomes of paramount importance. Whilst the trend towards wider democratic involvement with debates and practices in relation to natural issues is broadly welcomed [42], it creates additional dilemmas regarding roles and responsibilities. A wider suite of actors to more effectively implement control of the biosecurity border in response to the increased threat is logical. As Rumford [43] argues, ordinary people now play a real and substantial role in border protection. The health of the natural environment can be considered a public good from which benefits are widely shared and for which responsibility is thus shared. However, devolution of roles and activities to non-state actors without sufficient support and knowledge exchange can lead to flawed environmental management and conflict [15]. There is thus a need to maintain knowledge flows, networks and relationships to ensure borderwork (early detection) is optimized [16]. In this study, respondents acknowledged the limited capacity of dedicated inspectors. Whilst technical advances can support their work beyond visual inspection, the 'quantities of staff' remain a major limiting factor in early detection.

An interesting manifestation of roles and responsibilities in border performance was identified in citizen science. Citizen science can take many forms, from awareness and contribution of school children to the valuable management activities of expert volunteers [44]. Whilst the challenges as well as benefits of citizen science have been reviewed [44-46], there appears to have been little awareness of the potential of citizen science observations in plant health to raise substantial ethical and legal issues. State enthusiasm for citizens in surveillance could be limited if this input is not carefully managed. In theory, any individual citizen could observe and report a 'pest'. Firstly, whilst much citizen science occurs within structured programs in natural environments (e.g., [46]), the potential of the citizen scientist raises questions about access-is reporting from a garden center or from a forest owned by someone else legitimate? Does encouraging a surveillance culture support self-reporting by nurseries and a context of trust in which state bodies will be informed about incoming pests quickly enough to eradicate them or control spread? Secondly, it provokes uncertainty regarding authority; it potentially professionalizes a practice that has not been underpinned by training and education. Misidentification by enthusiastic amateurs is possible. Thirdly, it demands consideration of the consequences of citizen science. Such data must be monitored and validated before action is taken, but even if identification was confirmed, would citizen scientists realize the consequences of their actions for the local and wider environment, as well as for people's livelihoods and the accuracy of risk perception? Nonetheless, citizen science can be positive in facilitating education, offering people a role and agency and engaging and empowering citizens $[44,46]$, and so some forms of contribution need to be recognized and treated accordingly within border control practices.

Our study highlighted that all actors have roles that in some ways bear a responsibility for the border; the 'everywhere border' is also the 'everyone border'. Responsibility begins pre-border with those choosing to export into the UK. Inspectors have principal duties at key importation points, nurseries and other horticultural businesses have responsibility to observe and report, foresters must consider provenance and practices, communities should be vigilant in their woodlands. In fact, any member of the public(s) should contribute by adopting sustainable everyday practices (see Table 1). It is this latter aspect that creates the 'everyone' focus. Not only do those cycling or walking in woodlands or forests have a responsibility to clean their bikes and boots, but anyone purchasing 
a garden plant, firewood or product shipped in wood packaging or pallets should consider the geographical and market sources, as relevant. This notion of the 'everyone border' in terms of the natural environment thus overlaps with our understanding that sustainable behaviors and practices at an individual, organizational and sectoral level will lead to more sustainable outcomes (e.g., [42]). Whilst this spread of responsibility enables active democratic engagement with themes relating to our natural environment, it also creates ambiguities in relation to roles and responsibilities and arguably leaves individuals and societies open to more risk. We thus suggest a reconfiguration of the collaboration between state and non-state actors. This would require a transfer of the requirement to observe, correctly identify and report statutory or 'new' pests. It would also need investment in novel processes and practices, such as education and awareness, support, networking, monitoring, validation of non-expert notifications and the structures and development of new social norms to bolster and support borderwork $[16,47,48]$. Formal and non-formal incentives and regulations need to create a norm of joint responsibility across borders; without collaborative responsibility the borders remain unconnected. In this study, several actors blamed others. Balancing shared responsibilities and ensuring effective collaboration will also be supported by broader processes such as education, networking and monitoring.

Finally, in relation to roles, risks, responsibilities and resources we might also consider rights. Not only is it important who defends our borders and tree health and how they do it, it is also essential to ask why. "Biosecure citizenship" can be a mode of promoting a discourse of ecological rights as well as responsibility [49], ultimately eroding the Cartesian duality of people and nature [20].

\subsection{Power and Practice}

Biosecurity threats pose massive risks to the natural environment, human prosperity and social and cultural values and activities. This is a serious issue that demands a significant response. Other nations act powerfully in addressing these threats; for example, in New Zealand, biosecurity personnel have significant forms of authority and often pursue an eradication policy [50]. One Australian island has recently benefited from the efficacy (along with huge investment and effort) of a zero-tolerance biosecurity [51]. On Mainland Europe there have been monitoring and attempts to prevent the spread of many tree pests. Here in the UK, we retain some biophysical fortifications, and recent threats have enhanced our regulatory practices. However, the shift towards governance and a participative democracy also means that more of the public do not unquestioningly permit state authority to influence their lives; the state must exert power with empathy and sensitivity. "Biosecure citizenship" offers political potential for bordering, but must be nurtured within new forms of participation and community action [49].

Johnson et al. [25] unpack the tripartite understandings of the border. The formal border performance can be seen to be a manifestation of territorial might and power that stems from sovereignty (see also [29]). In tree health, we see this manifesting not only as national but as regional power, through European regulations. We noted formal border performances not merely on UK soil but also through pre-border inspections. The biological attributes of biosecurity threats caused several respondents to call for more power to be exerted overseas, through required inspections and certifications before importation. The vested interest of producers overseas in selling biomaterials in the UK has led to compliance and sometimes even requests for capacity building and skills training in countries of origin. It seems that a viable response to biosecurity threats is to assert power and control the pre-border as much as possible, causing importers to pay costs. The policy context thus becomes critical, with regulations and pre-border checks especially designed to stop disease entry rather than focus on early detection of disease, a strategy based on the idea that 'prevention is better than cure'. However, regulation is only as good as its enforcement, and the identification of "leaky" and "porous" borders referred to policy that was ineffective in practice, in the second sense of border performance.

The practical everyday performance of the border [25] proved to be diverse and diffuse, from formal state-driven inspections at ports of entry, to containers being unpacked in nurseries, to serendipitous 
observations in woodlands across the country. Some of our respondents were consciously performing this border control, but other actors seemed to be more of an audience than performers, watching the drama of ash dieback unfold in horror without having a script from which to play. Finally, Johnson et al. [25] have discussed the discursive nature of the border. Many of our respondents were uncomfortable at being asked to define the border-this concept has not been much debated within the practice of biosecurity control. We suggest that conscious discussion of this notion could enable a more appropriate allocation of roles and responsibilities, and ultimately result in more effective border control.

We propose that it may be better to support effective processes and practices than to highlight specific pests. There is always a new pest on the horizon, but if the state considers how to promote biosecure citizenship [49] and enhance pro-sustainable behaviors, leading people to adopt effective practices as outlined above and detailed in recommendations below, enhanced tree health could result.

New configurations of 'the border' were in effect put into place through regulation, where statutory reporting of different pests and pathogens is implemented. This places the responsibility onto a wider range of actors, including those with significant personal interest and some horticultural expertise, such as tree nurseries, but also those with a personal interest and less knowledge, such as community members around community woodlands or garden owners, and those with little personal interest beyond 'the common good' and less or no knowledge, such as those pursuing outdoors recreational activity. Knowledge production and exchange within and across state territorial borders (mainland Europe-UK), political boundaries (Scotland-England), sectors (nurseries, garden centers, landscape architecture), organizations (citizen science NGOs, government agencies) and 'the publics' is essential to control of a biosecurity border. The border is thus manifest also as 'knowledge', and the practices and performances of the border (through pest identification and reporting) are enabled only where there is sufficient understanding and skill. Poor knowledge or incorrect information limit detection and may lead to inappropriate border control actions.

The changing nature of biological organisms and the need for adaptive tree health management in response to changing threats [2] creates additional challenges for knowledge in relation to the border; not only do we manage knowns, we also have to manage unknowns. This presents a greater imperative for processes and networks rather than static regulation and roles. We thus see that border control practices and performances have to provide information and awareness, education, certification, regulation, inspection and penalties across a range of actors. Empathetic, empowering forms of border control practice could lead to positive outputs, strengthening nature connection and democratic engagement.

\subsection{Consequences for Plant Health and Biosecurity}

We demonstrate the multiplicity of the border and the complexity of roles and responsibilities across a range of actors in tree health. This produces consequences for how plant health and biosecurity should be managed. It is clear that environmental health is a public good; everyone suffers from a degraded natural environment. What is not clear is how everyone can contribute towards environmental health in this case. We identified an 'everyone border' that draws in the public, but raises further questions over how and where biosecurity threats should be managed. The UK government has invested heavily in plant health over the past few years, with new policy and personnel support, investment in knowledge flows and networks and support of research to enhance biosecurity. Our study suggests an even wider responsibility could come with liability if biomaterials transgress to contaminate and attack our native habitats and species. It is not clear who should bear the brunt of this liability. This raises questions around whether ignorance is a defense in these cases, and if not, if the UK government can prosecute individuals who fail to report on and contain biological threats. At this key point in history, we also remain poised to see if the border will be strengthened by post-Brexit UK focus, or whether the EU legislation that currently affects us will be diluted by those demanding market movement at all costs. 
Some recommendations can be drawn from this study. In the UK, a recent focus on plant health has led to a suite of actions, some of which already address our recommendations, at least in part. Recognizing the multiplicity of the border can lead to a wider strategy to secure it. Appropriate rules and regulations can be developed, such as more stringent pre-border inspections, to strengthen the many manifestations of the border. However, such regulations need to be implemented effectively. For plant movement, tightening regulations and agreements remains critical in defining legal movement whilst creating impetus for illegal movement and "porous" borders. In order to ensure knowledge flows and collaborative responses, task groups and networks need to be established and maintained to enable more resilience in response to crises, including industry as well as state and third sector. To mobilize the 'everyone' in the 'everyone border', awareness, education and nature connection through outdoor learning, citizen science and formal and informal schemes are required as part of wider efforts in education for sustainable development [52]. Clarification of roles and responsibilities will facilitate effective border control. Finally, structures to facilitate pro-sustainable practices should be provided, such as taps and hoses to clean bikes and boots at trail heads and certification of sustainably sourced plant materials in garden centers.

Whilst this study focuses on the border in relation to plant health, as some of respondents pointed out, in some contexts the border may not be a useful way to understand the movement of plant pests and pathogens. There is a need to consider the concept of 'nations without borders' in the light of planetary boundaries and discourse around the Anthropocene [23]; this study demonstrates empirically the need for the greater trans-border, international collaboration to address environmental concerns that is promoted by D'Souza. Our study also empirically interrogates the notion of 'biopolitics' [50], which is often conceptually debated, yet rarely explored in practice. Undertaking conceptual analysis of the border in relation to biosecurity, and especially plant health, and locating qualitative research within a nation and context has offered new insights for both theory and practice.

\section{Conclusions}

In this debate on tree health and the border, we further contribute to questions raised by Ramutsindela [20]; we are exploring "a post-binary approach to nature and border that recognizes feedback loops between society and the environment". Whilst those in border studies have discussed biological issues, we take an environmental starting point (the need to support plant health) and bring in debate on social dimensions. Biophysical characteristics remain important in biosecurity more than in some other border debates; but the increasing porosity in different areas is acknowledged.

This research has demonstrated that the border can be manifested and understood in multiple ways for tree health and wider biosecurity concerns: conceptually, biologically, geo-politically and in terms of detection activities and 'borderwork'. There is evidence for an 'everywhere border' for biosecurity, but we also introduce and define the 'everyone border' in which the responsibility for border control is shared more widely across a range of actors, state, non-state and in hybrid organizations and roles. Not everyone is yet aware of their responsibilities, and there is a need to enhance knowledge flows to increase awareness and develop stronger networks to enhance collaborative borderwork. The consequences of understanding the border and how the border can be defended create a suite of actions for state and non-state actors to undertake. However, they also raise questions as to when we defend and when we accept the indefensible and adapt? Whilst there are management guidelines to support regulation and action in this regard (e.g., the UK Risk Register), we raise these questions in a theoretical as well as practical framing. Clark [50] suggests that biosecurity can be part of a flexible program of resilience. This paper does not fully answer these questions, but our research demonstrates that the maintenance of tree health is important not only in maintaining the integrity of our forests and woodlands, but also in supporting the public, private and third sectors. Tree health border challenges are a manifestation of wider sustainability issues such as climate change, globalization and neoliberalism. These questions thus also enable us to explore how relationships between people and 
trees/nature can be deepened, how we can stimulate democratic engagement and how we can envision and enact more sustainable futures.

Author Contributions: Conceptualization, R.M.W., S.L. and M.M.; Project methodology, M.M., R.M.W. and G.J.; Data Collection M.M. and R.M.W.; Analysis, R.M.W.; Writing, Review \& Editing, R.M.W., S.L., M.M. and G.J.

Funding: This research was partially funded by UK BBSRC grant BB/L012030/1 for the project New approaches for the early detection of tree health pests and pathogens.

Conflicts of Interest: The authors declare no conflict of interest.

\section{References}

1. Freer-Smith, P.H.; Webber, J.F. Tree pests and diseases: The threat to biodiversity and the delivery of ecosystem services. Biodivers. Conserv. 2015, 26, 3167-3181. [CrossRef]

2. Marzano, M.; Allen, W.; Haight, R.G.; Holmes, T.P.; Keskitalo, E.C.H.; Langer, E.R.L.; Shadbolt, M.; Urquhart, J.; Dandy, $\mathrm{N}$. The role of the social sciences and economics in understanding and informing tree biosecurity policy and planning: A global summary and synthesis. Biol. Invasions 2017, 19, 3317-3332. [CrossRef]

3. Boyd, I.L.; Freer-Smith, P.H.; Gilligan, C.A.; Godfray, H.C.J. The Consequence of Tree Pests and Diseases for Ecosystem Services. Science 2013, 342, 1235773. [CrossRef] [PubMed]

4. United Nations. Transforming Our World: The 2030 Agenda for Sustainable Development; United Nations: New York, NY, USA, 2015.

5. Eschen, R.; Britton, K.; Brockerhoff, E.G.; Burgess, T.; Dalley, V.; Epanchin-Niell, R.; Gupta, K.; Hardy, G.; Huang, Y.; Kenis, M.; et al. International variation in phytosanitary legislation and regulations governing importation of plants for planting. Environ. Sci. Policy 2015, 51, 228-237. [CrossRef]

6. FAO. International Standards for Phytosanitary Measures ISPM 15 Regulation of Wood Packaging Material in International Trade; FAO: Rome, Italy, 2009.

7. Klapwijk, M.J.; Hopkins, A.J.M.; Eriksson, L.; Pettersson, M.; Schroeder, M.; Lindelöw, Å.; Rönnberg, J.; Keskitalo, E.C.H.; Kenis, M. Reducing the risk of invasive forest pests and pathogens: Combining legislation, targeted management and public awareness. Ambio 2016, 45, 223-234. [CrossRef]

8. Stenlid, J.; Oliva, J.; Boberg, J.B.; Hopkins, A.J. Emerging Diseases in European Forest Ecosystems and Responses in Society. Forests 2011, 2, 486-504. [CrossRef]

9. UK Government. A Green Future: Our 25 Year Plan to Improve the Environment. Annex 1: Supplementary Evidence Report. 2018. Available online: https://assets.publishing.service.gov.uk/government/ uploads/system/uploads/attachment_data/file/673492/25-year-environment-plan-annex1.pdf (accessed on 16 July 2019).

10. The Guardian. Ash Dieback Expected to Cost British Economy Nearly £15bn. 6 May 2019. Available online: https://www.theguardian.com/environment/2019/may/06/ash-dieback-expected-costbritish-economy-15bn (accessed on 19 July 2019).

11. Urquhart, J.; Marzano, M.; Potter, C. The Human Dimensions of Forest and Tree Health: Global Perspectives; Palgrave Macmillan: Basingstoke, UK, 2018.

12. DEFRA. Tree Health Management Plan; Department for Food, Environment and Rural Affairs: London, UK, 2014.

13. Dobson, A.; Barker, K.; Taylor, S.L. Biosecurity: The Socio-Politics of Invasive Species and Infectious Diseases; Routledge: Abingdon, UK, 2013.

14. Dobson, A. Environmental citizenship: Towards sustainable development. Sustain. Dev. 2007, 15, $276-285$. [CrossRef]

15. Davies, A.L.; White, R.M. Collaboration in natural resource governance: Reconciling stakeholder expectations in deer management in Scotland. J. Environ. Manag. 2012, 112, 160-169. [CrossRef] [PubMed]

16. White, R.M. "But who do we speak to?" Stakeholder engagement for forest health across spatial and temporal scales in an era of austerity. J. For. Ecol. Manag. 2018, 417, 313-322. [CrossRef]

17. Marzano, M.; White, R.M.; Jones, G. Enhancing socio-technological innovation for tree health through stakeholder participation in biosecurity science. In Human Dimensions in Forest and Tree Health; Urquhart, J., Potter, C., Marzano, M., Eds.; Palgrave Macmillan: Basingstoke, UK, 2018; pp. 299-329. 
18. Dandy, N.; Marzano, M.; Porth, E.F.; Urquhart, J.; Potter, C. Who has a stake in ash dieback? A conceptual framework for the identification and categorisation of tree health stakeholders. In Dieback of European Ash (FRaxinus Spp.): Consequences and Guidelines for Sustainable Management; Vasaitis, R., Enderle, R., Eds.; Swedish University of Agricultural Sciences: Uppsala, Sweden, 2017; pp. 15-26.

19. Marzano, M.; Dandy, N.; Bayliss, H.R.; Porth, E.; Potter, C. Part of the solution? Stakeholder awareness, information and engagement in tree health issues. Biol. Invasions 2015, 17, 1961-1977. [CrossRef]

20. Ramutsindela, M. Natured Borders. Geoforum 2015, 61, 135-137. [CrossRef]

21. Wonders, N.A. Global flows, semi-permeable borders and new channels of inequality: Bordercrossers and border performativity. In Borders, Mobility and Technologies of Control; Pickering, S., Weber, L., Eds.; Springer: Amsterdam, The Netherlands, 2006.

22. Agnew, J. Borders on the mind: Re-framing border thinking. Ethics Glob. Polit. 2008, 1, 175-191. [CrossRef]

23. D'Souza, R. Nations without Borders: Climate Security and the South in the Epoch of the Anthropocene. Strat. Anal. 2015, 39, 720-728. [CrossRef]

24. Paasi, A. Bounded spaces in a 'borderless world': Border studies, power and the anatomy of territory. $J$. Power 2009, 2, 213-234. [CrossRef]

25. Johnson, C.; Jones, R.; Paasi, A.; Amoore, L.; Mountz, A.; Salter, M.; Rumford, C. Interventions on rethinking 'the border' in border studies. Polit. Geogr. 2011, 30, 61-69. [CrossRef]

26. Balibar, E. Politics and the Other Scene; Verso Trade: Berlin, Germany, 2002.

27. Paasi, A.; Prokkola, E.K.; Saarinen, J.; Zimmerbauer, K. Borderless Worlds for Whom? Ethics, Moralities and Mobilities; Routledge: Abingdon, UK, 2018.

28. Leahy, S.; McKee, K.; Crawford, J. Generating confusion, concern, and precarity through the Right to rent scheme in Scotland. Antipode 2018, 50, 604-620. [CrossRef]

29. Chambers, P. The Embrace of Border Security: Maritime Jurisdiction, National Sovereignty, and the Geopolitics of Operation Sovereign Borders. Geopolitics 2015, 20, 404-437. [CrossRef]

30. Mountz, A. Specters at the Port of Entry: Understanding State Mobilities through an Ontology of Exclusion. Mobilities 2011, 6, 317-334. [CrossRef]

31. UK Government. UK Biological Security Strategy. July 2019. Available online: https://www.gov.uk/ government/publications/biological-security-strategy (accessed on 21 July 2019).

32. DEFRA. UK Plant Health Risk Register. 27 June 2019. Available online: https://secure.fera.defra.gov.uk/ phiw/riskRegister/ (accessed on 23 July 2019).

33. Amoore, L. Biometric borders: Governing mobilities in the war on terror. Polit. Geogr. 2006, 25, 336-351. [CrossRef]

34. Prell, C.; Hubacek, K.; Reed, M. Stakeholder Analysis and Social Network Analysis in Natural Resource Management. Soc. Nat. Resour. 2009, 22, 501-518. [CrossRef]

35. Reed, M.S.; Graves, A.; Dandy, N.; Posthumus, H.; Hubacek, K.; Morris, J.; Prell, C.; Quinn, C.H.; Stringer, L.C. Who's in and why? A typology of stakeholder analysis methods for natural resource management. J. Environ. Manag. 2009, 90, 1933-1949. [CrossRef] [PubMed]

36. Freeman, R.E. The Politics of Stakeholder Theory: Some Future Directions. Bus. Ethics Q. 1994, 4, 409-421. [CrossRef]

37. Lecuyer, L.; White, R.M.; Schmook, B.; Lemay, V.; Calmé, S. The construction of feelings of justice in environmental management: An empirical study of multiple biodiversity conflicts in Calakmul, Mexico. J. Environ. Manag. 2018, 213, 363-373. [CrossRef] [PubMed]

38. Bryman, A. Social Research Methods, 4th ed.; Oxford University Press: New York, NY, USA, 2012.

39. Burridge, A.; Gill, N.; Kocher, A.; Martin, L. Polymorphic borders. Territ. Polit. Gov. 2017, 5, $239-251$. [CrossRef]

40. Sohn, C. Navigating borders multiplicity: The critical potential of assemblage. Area 2016, 48, $183-189$. [CrossRef]

41. Carnegie, A.J.; Nahrung, H.F. Post-Border Forest Biosecurity in Australia: Response to Recent Exotic Detections, Current Surveillance and Ongoing Needs. Forests 2019, 10, 336. [CrossRef]

42. Jordan, A. The Governance of Sustainable Development: Taking Stock and Looking Forwards. Environ. Plan. C Gov. Policy 2008, 26, 17-33. [CrossRef]

43. Rumford, C. Theorizing Borders. Eur. J. Soc. Theory 2006, 9, 155-169. [CrossRef] 
44. Conrad, C.C.; Hilchey, K.G. A review of citizen science and community-based environmental monitoring: Issues and opportunities. Environ. Monit. Assess. 2011, 176, 273-291. [CrossRef]

45. Leeuwis, C.; Cieslik, K.; Aarts, M.; Dewulf, A.; Ludwig, F.; Werners, S.; Struik, P. Reflections on the potential of virtual citizen science platforms to address collective action challenges: Lessons and implications for future research. NJAS Wagening. J. Life Sci. 2018, 86, 146-157. [CrossRef]

46. Dickinson, J.L.; Zuckerberg, B.; Bonter, D.N. Citizen Science as an ecological research tol: Challenges and benefits. Annu. Rev. Ecol. Evol. Syst. 2010, 41, 149-172. [CrossRef]

47. Leiserowitz, A.A.; Kates, R.W.; Parris, T.M. Sustainability Values, Attitudes, and Behaviors: A Review of Multinational and Global Trends. Annu. Rev. Environ. Resour. 2006, 31, 413-444. [CrossRef]

48. Shove, E.A.; Walker, G.P. Governing transitions in the sustainability of everyday life. Res. Policy 2010, 39, 471-476. [CrossRef]

49. Barker, K. Biosecure citizenship: Politicising symbiotic associations and the construction of biological threat. Trans. Inst. Br. Geogr. 2010, 35, 350-363. [CrossRef]

50. Clark, N. Mobile Life: Biosecurity Practices and Insect Globalization. Sci. Cult. 2013, 22, 16-37. [CrossRef]

51. Scott, J.K.; McKirdy, S.J.; Van Der Merwe, J.; Green, R.; Burbidge, A.A.; Pickles, G.; Hardie, D.C.; Morris, K.; Kendrick, P.G.; Thomas, M.L.; et al. Zero-tolerance biosecurity protects high-conservation-value island nature reserve. Sci. Rep. 2017, 7, 772. [CrossRef] [PubMed]

52. Giangrande, N.; White, R.M.; East, M.; Jackson, R.; Clarke, T.; Coste, M.S.; Penha-Lopes, G. A Competency Framework to Assess and Activate Education for Sustainable Development: Addressing the UN Sustainable Development Goals 4.7 Challenge. Sustainability 2019, 11, 2832. [CrossRef]

(C) 2019 by the authors. Licensee MDPI, Basel, Switzerland. This article is an open access article distributed under the terms and conditions of the Creative Commons Attribution (CC BY) license (http://creativecommons.org/licenses/by/4.0/). 